\title{
Use of traditional complementary and alternative medicine
} (TCAM) by HIV patients prior to initiating ART in KwaZulu-Natal, South Africa

\author{
K Peltzer ${ }^{1}$, N Friend-du Preez ${ }^{2}$, S Ramlagan ${ }^{1}$, H Fomundam ${ }^{3}$ and \\ J Anderson*2
}

Address: ${ }^{1}$ Health Systems Research Unit, Social Aspect of HIV/AIDS and Health, Human Sciences Research Council, Pretoria, South Africa, ${ }^{2}$ Homerton University Hospital NHS Foundation Trust, London, UK and ${ }^{3}$ HIV/AIDS Pharmaceutical Care Program-ROADS Project, Pretoria, South Africa

* Corresponding author

from Ninth International Congress on Drug Therapy in HIV Infection

Glasgow, UK. 9-13 November 2008

Published: 10 November 2008

Journal of the International AIDS Society 2008, I I (SuppI I):P73 doi:I0.I I86/I758-2652-I I-SI-P73

This abstract is available from: http://www.jiasociety.org/content/II/SI/P73

(c) 2008 Peltzer et al; licensee BioMed Central Ltd.

\section{Purpose of the study}

Traditional medicine use has been reported as common among individuals with moderate and advanced HIV disease $[1,2]$. Funded by Tibotec's REACH Initiative, this cross-sectional study aimed to assess the use of traditional complementary and alternative medicine (TCAM) by HIV patients prior to initiating antiretroviral therapy in three public hospitals in KwaZulu-Natal, South Africa.

\section{Methods}

Using systematic sampling, 618 HIV-positive patients were recruited from outpatient departments at three hospitals to take part in semi-structured interviewer-administered interviews.

\section{Summary of results}

Survey results show that TCAM was commonly used for HIV in the past 6 months by study participants (51.3\%) and $29.6 \%$ of participants used herbal therapies. The use of micronutrients $(42.9 \%)$ was excluded from TCAM since most vitamins were provided by the health facility. Herbal therapies were the most expensive treatment, costing on average 128 Rand (US\$16) per patient per month. Most participants $(90 \%)$ indicated that their health care provider was not aware that they were taking herbal therapies for HIV. Herbal therapies were mainly used for pain relief $(87.1 \%)$ and spiritual practices or prayer for stress relief (77.6\%). Regression analyses identified being on a disability grant, having less income and rural residence of the patient to be associated with use of herbs. Being on a disability grant, being female and family members not contributing to household income were predictors of overall TCAM use. TCAM use in females was particularly related to religious and spiritual practices. Women (42\%) in this sample were much more likely to belong to charismatic churches than men $(21 \%)$ and used faith healing methods $(40 \%$ for women and $20 \%$ for men, respectively), and spiritual practices or prayer (15\% vs. $7 \%)$ more often than men.

\section{Conclusion}

Traditional herbal therapies and TCAM are commonly used by HIV treatment naïve outpatients of public health facilities in South Africa. Health care providers should routinely screen patients on TCAM use when initiating ART and also during follow-up and monitoring, keeping in mind that these patients may not fully disclose other therapies. Co-location of services, including voluntary organizations offering spiritual and/or holistic health care advice, may help to address patients' needs where health care providers lack the time or knowledge to adequately address these issues. 


\section{References}

I. Babb DA, et al.: Use of traditional medicine by HIV-infected individuals in South Africa in the era of antiretroviral therapy. Psychol Health Med 2007, I 2(3):3 |4-320.

2. Malangu N: Self-reported use of traditional, complementary and over-the-counter medicines by HIV-infected patients on antiretroviral therapy in Pretoria, South Africa. Afr J Trad CAM 2007, 4(3):273-278.

Publish with Bio Med Central and every scientist can read your work free of charge

"BioMed Central will be the most significant development for disseminating the results of biomedical research in our lifetime."

Sir Paul Nurse, Cancer Research UK

Your research papers will be:

- available free of charge to the entire biomedical community

- peer reviewed and published immediately upon acceptance

- cited in PubMed and archived on PubMed Central

- yours - you keep the copyright

Submit your manuscript here:

http://www.biomedcentral.com/info/publishing_adv.asp 